\title{
Analyzing the Implications of Climate Data on Plant Hardiness Zones for Green Infrastructure Planning: Case Study of Knoxville, Tennessee and Surrounding Region
}

Approved for public release. Distribution is unlimited.
Linda Sylvester

Olufemi Omitaomu Esther Parish July 2016 


\title{
DOCUMENT AVAILABILITY
}

Reports produced after January 1, 1996, are generally available free via US Department of Energy (DOE) SciTech Connect.

Website http://www.osti.gov/scitech/

Reports produced before January 1, 1996, may be purchased by members of the public from the following source:

\author{
National Technical Information Service \\ 5285 Port Royal Road \\ Springfield, VA 22161 \\ Telephone 703-605-6000 (1-800-553-6847) \\ TDD 703-487-4639 \\ Fax 703-605-6900 \\ E-mail info@ntis.gov \\ Website http://www.ntis.gov/help/ordermethods.aspx
}

Reports are available to DOE employees, DOE contractors, Energy Technology Data Exchange representatives, and International Nuclear Information System representatives from the following source:

Office of Scientific and Technical Information

PO Box 62

Oak Ridge, TN 37831

Telephone 865-576-8401

Fax 865-576-5728

E-mail reports@osti.gov

Website http://www.osti.gov/contact.html

This report was prepared as an account of work sponsored by an agency of the United States Government. Neither the United States Government nor any agency thereof, nor any of their employees, makes any warranty, express or implied, or assumes any legal liability or responsibility for the accuracy, completeness, or usefulness of any information, apparatus, product, or process disclosed, or represents that its use would not infringe privately owned rights. Reference herein to any specific commercial product, process, or service by trade name, trademark, manufacturer, or otherwise, does not necessarily constitute or imply its endorsement, recommendation, or favoring by the United States Government or any agency thereof. The views and opinions of authors expressed herein do not necessarily state or reflect those of the United States Government or any agency thereof. 
Computational Sciences and Engineering Division Geographic Information Science and Technology Group

Analyzing the Implications of Climate Data on Plant Hardiness Zones for Green Infrastructure Planning: Case Study of Knoxville, Tennessee and Surrounding Region

\author{
Linda Sylvester \\ Olufemi Omitaomu \\ Esther Parish
}

Date Published:

July 2016

Prepared by

OAK RIDGE NATIONAL LABORATORY

Oak Ridge, TN 37831-6283

managed by

UT-BATTELLE, LLC

for the

US DEPARTMENT OF ENERGY

under contract DE-AC05-00OR22725 



\section{CONTENTS}

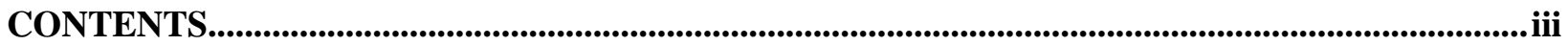

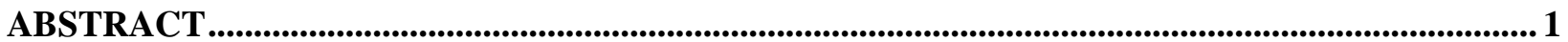

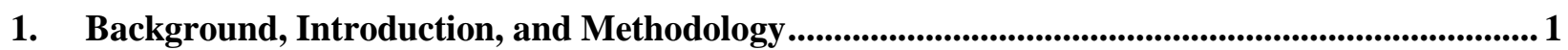

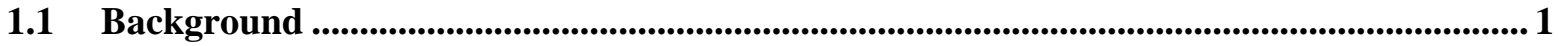

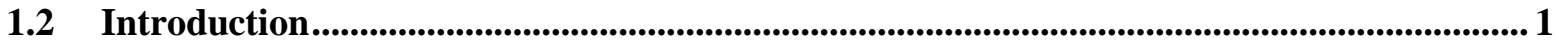

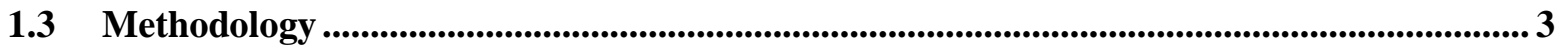

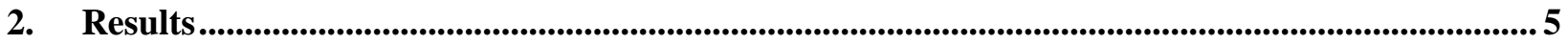

2.1 ACCESS Model Plant Hardiness Zone Calculation Results .............................................5

2.2 BCC Model Plant Hardiness Zone Calculation Results ....................................................6 6

2.3 CCSM4 Model Plant Hardiness Zone Calculation Results .................................................... 7

2.4 CMCC Model Plant Hardiness Zone Calculation Results ..................................................... 8

2.5 FGOALS Model Plant Hardiness Zone Calculation Results .............................................99

2.6 GFDL Model Plant Hardiness Zone Calculation Results ........................................................ 10

2.7 IPSL Model Plant Hardiness Zone Calculation Results............................................................ 11

2.8 MPI Model Plant Hardiness Zone Calculation Results....................................................... 12

2.9 MRI Model Plant Hardiness Zone Calculation Results .......................................................... 13

2.10 NorESM Model Plant Hardiness Zone Calculation Results ............................................ 14

2.11 Summary of Climate Model Plant Hardiness Zone Calculations.......................................... 15

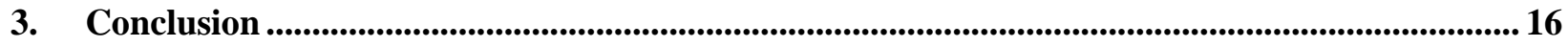

Appendix A. Hardiness Zones for Recommended Trees in Knoxville, Tennessee..............................A-2 


\begin{abstract}
Downscaled climate data for Knoxville, Tennessee and the surrounding region were used to investigate future changing Plant Hardiness Zones due to climate change. The methodology used is the same as the US Department of Agriculture (USDA), well-known for their creation of the standard Plant Hardiness Zone map used by gardeners and planners. USDA data were calculated from observed daily data for 1976-2005. The modeled climate data for the past is daily data from 1980-2005 and the future data is projected for 2025-2050. The average of all the modeled annual extreme minimums for each time period of interest was calculated. Each $1 \mathrm{~km}$ raster cell was placed into zone categories based on temperature, using the same criteria and categories of the USDA. The individual models vary between suggesting little change to the Plant Hardiness Zones to suggesting Knoxville moves into the next two Hardiness Zones. But overall, the models suggest moving into the next warmer Zone.

USDA currently has the Knoxville area categorized as Zone 7a. None of the Zones calculated from the climate data models placed Knoxville in Zone 7a for the similar time period. The models placed Knoxville in a cooler Hardiness Zone and projected the area to increase to Zone 7. The modeled temperature data appears to be slightly cooler than the actual temperature data and this may explain the zone discrepancy. However, overall Knoxville is projected to increase to the next warmer Zone. As the modeled data has Knoxville, overall, moving from Zone 6 to Zone 7, it can be inferred that Knoxville, Tennessee may increase from their current Zone 7 to Zone 8.
\end{abstract}

\title{
1. Background, Introduction, and Methodology
}

\subsection{Background}

Oak Ridge National Laboratory (ORNL) and the City of Knoxville, Tennessee have partnered to work on a Laboratory Directed Research and Development (LDRD) project towards investigating climate change, mitigation, and adaptation measures in mid-sized cities. One project the city of Knoxville indicated interest in was determining the best locations to install green infrastructure installations to reduce future flooding and promote precipitation infiltration. With projected changes to the precipitation regime and minimum and maximum daily temperatures the thought that trees and plants that are currently recommended for planting may no longer be appropriate or ideal in a changed climate. The following research explores the changes that may occur to Plant Hardiness Zones in the Knoxville, Tennessee area.

\subsection{Introduction}

The US Department of Agriculture (USDA) Plant Hardiness Zones are used for planting planning purposes as the Zones serve as an indicator for optimal climate conditions. The most recent 2012 USDA Plant Hardiness Zones (Figure 1) are based on the average annual extreme minimum temperature experienced in the past 30-year period (1976-2005). ${ }^{1}$ The 13 Zones are delineated by 10-degree Fahrenheit increments with 5-degree Fahrenheit subzones "a" and "b". Plants are categorized into one or several of the Zones by the ability of the plant to survive at the average extreme minimum temperature experienced within the Zone. Three editions of USDA Plant Hardiness Zone Maps have been produced: 1960, 1990, and 2012.

Knoxville, Tennessee (within Knox County) is noted as Plant Hardiness Zone 7 according to the latest USDA publication (Figure 2). Knoxville is officially within the specific Zone 7a (average extreme

\footnotetext{
${ }^{1}$ USDA Plant Hardiness Zone Map, 2012. Agricultural Research Service, U.S. Department of Agriculture. Accessed from http://planthardiness.ars.usda.gov
} 
minimum temperature of $\left.0-5^{\circ} \mathrm{F}\right)$. It should be noted that within any Zone there may be local characteristics that lead to the creation of microclimates, varying the conditions within the zonal designation. Knoxville had previously (1990) been designated as Zone $6 \mathrm{~b}$ and has thus increased in temperature to move into the next warmer Hardiness Zone, Zone 7a. The Arbor Day Foundation, known for its promotion of tree planting, has also calculated Plant Hardiness Zones and has published a map of the changes and shifts in Plant Hardiness Zones between 1990 and 2015 (Figure 3). The shifting Hardiness Zones can be seen across the Continental United States and illustrates the warming transformation of the Hardiness Zone for Knoxville, TN.

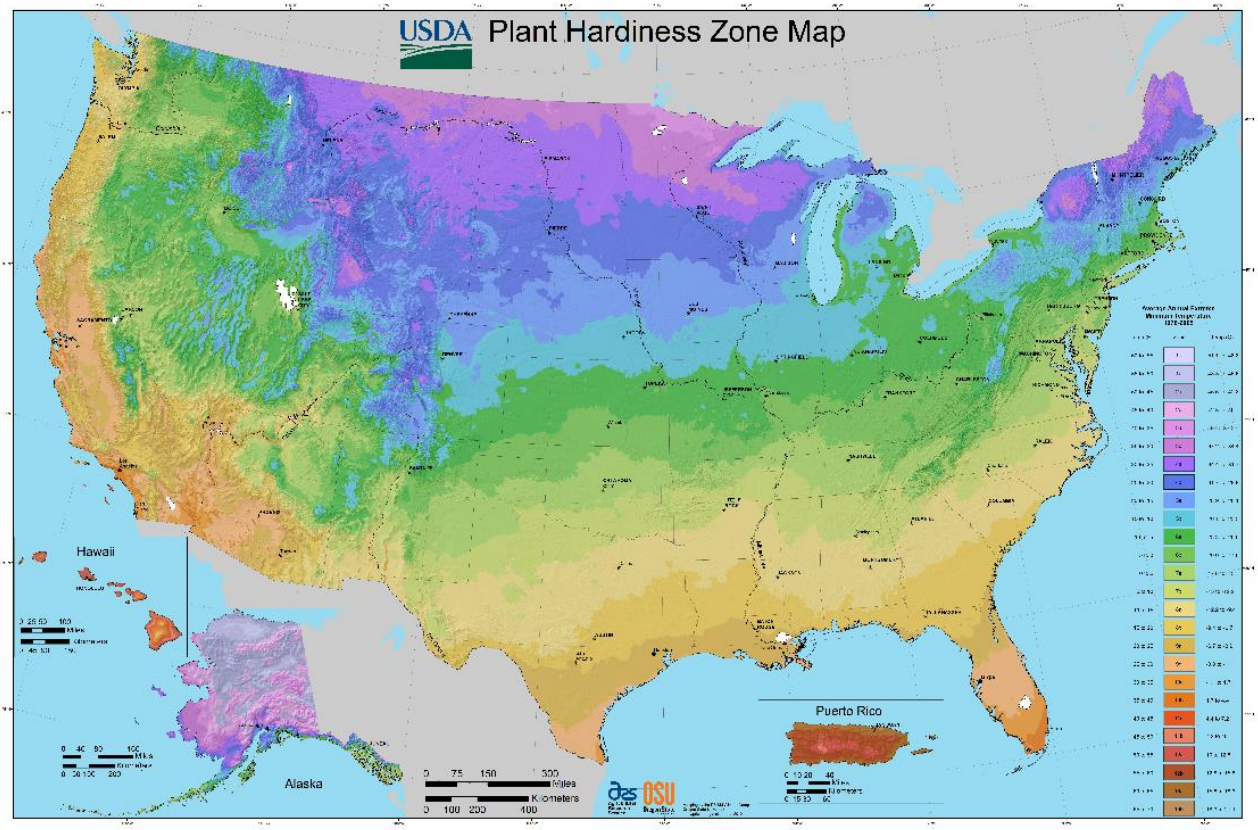

Figure 1: 2012 USDA Plant Hardiness Zones

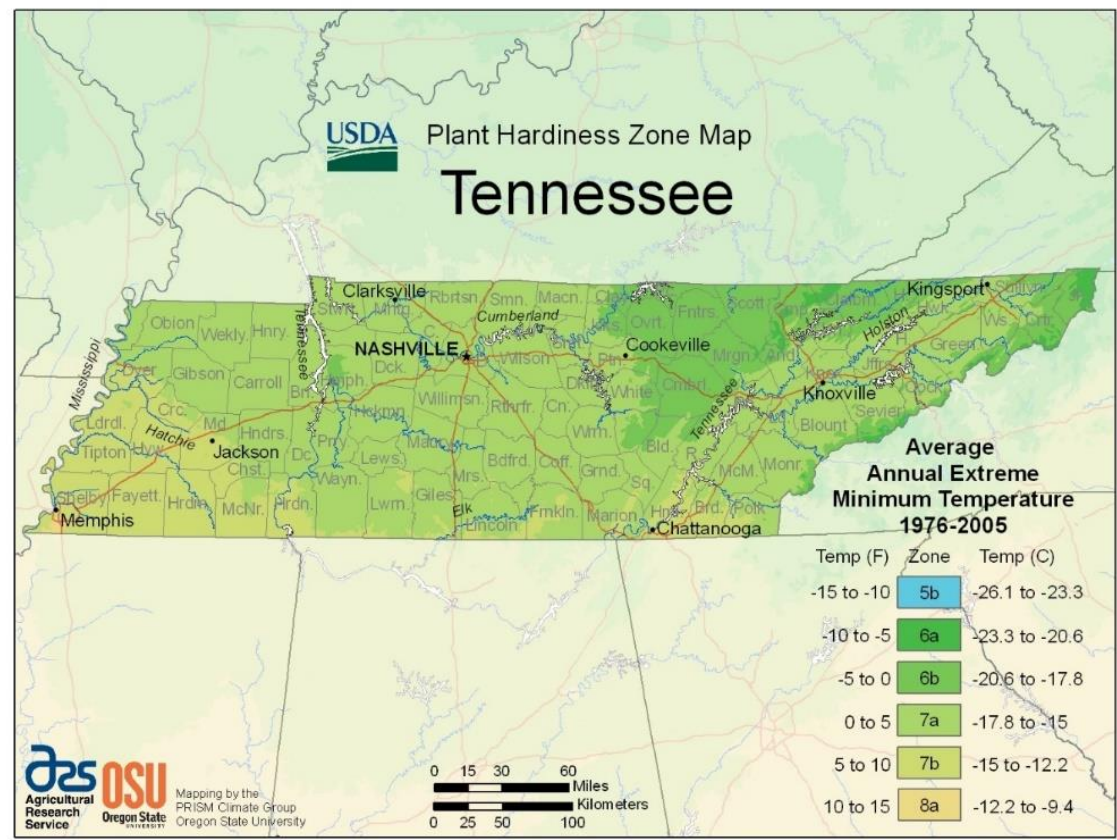

Figure 2: USDA 2012 Plant Hardiness Zone Map for Tennessee 
Differences Between 1990 USDA Hardiness

Zones and 2015 Arborday.org Hardiness Zones

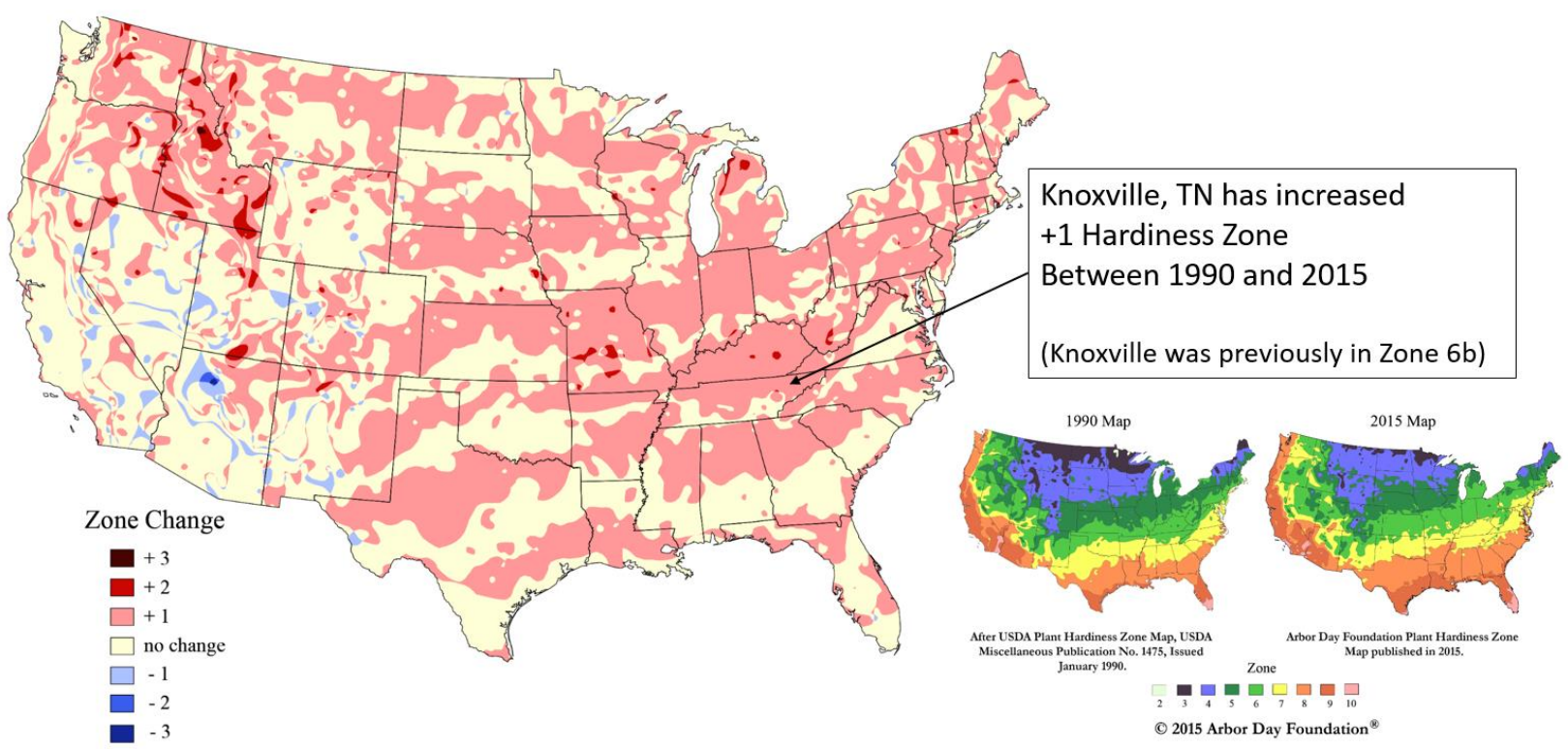

Figure 3: Plant Hardiness Zone Shifts between Arbor Day Foundation (2015) and USDA (1990) Hardiness Zone Calculations. ${ }^{2}$

Climate adaptation in cities often recommends planting trees to mitigate effects from the Urban Heat Island (UHI). Predicting future tree distribution and understanding how different tree species adapt is a crucial component to this mitigation effort, as the survival of the species and success of tree growth is crucial.

Researchers Lanza and Stone ${ }^{3}$ have investigated past and present tree distributions to understand how various tree species have adapted to changing climate conditions, as defined by USDA's Plant Hardiness Zones. The Southeastern area of the United States was found to have a greater shift in Hardiness Zones than any other region between 1961-2010. The Atlanta, Georgia metropolitan area, just south of Knoxville, was found to have already had a shift in Hardiness Zone that now excludes ten tree species that had previously been suitable for that region in Georgia. If the Hardiness Zones continue to shift northward, an additional 27 species may be lost.

Knoxville, Tennessee is currently designing areas for green infrastructure to assist with storm water mitigation. Understanding which tree species may be suitable for installation is important and therefore future shifts in Plant Hardiness Zones were to be calculated. The daily minimum temperatures for ten climate models were used as the basis for calculating past and future Plant Hardiness Zones. The change and shifts that occur, which may have an effect on tree species selection for green infrastructure installations in Knoxville, Tennessee, were calculated.

\subsection{Methodology}

Calculation of Plant Hardiness Zones was conducted with the use of ten different climate models, focusing on the Knoxville, Tennessee area. The ten climate models are downscaled to $1 \mathrm{~km}$ gridded resolution by Oak Ridge National Laboratory. The models that were used are summarized in Table 1.

\footnotetext{
${ }^{2}$ https://www.arborday.org/media/map_change.cfm

${ }^{3}$ Lanza, K., \& Stone, B. (2016). Climate adaptation in cities: What trees are suitable for urban heat management?

Landscape and Urban Planning, 153, 74-82. http://doi.org/10.1016/j.landurbplan.2015.12.002
} 
The models summarized temperature data for the past period of 1980-2005 and the future period of 2025-2050 and reported values at the daily scale ${ }^{4}$.

Table 1: Brief summary of downscaled climate models used to calculate Plant Hardiness Zones in Knoxville, TN.

\begin{tabular}{|c|c|c|c|c|c|c|c|c|c|c|}
\hline \multirow[t]{2}{*}{ Model } & \multirow[t]{2}{*}{ Center } & \multicolumn{7}{|c|}{ Model Components } & \multirow{2}{*}{$\begin{array}{l}\text { Atmospheric } \\
\text { Resolution }\end{array}$} & \multirow{2}{*}{$\begin{array}{l}\text { Vertical } \\
\text { levels in } \\
\text { atmosphere }\end{array}$} \\
\hline & & 官 & 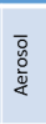 & 突 & 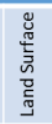 & 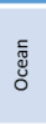 & 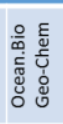 & $\begin{array}{l}\frac{g}{\widetilde{g}} \\
\dddot{\Omega}\end{array}$ & & \\
\hline ACCESS & $\begin{array}{l}\text { Commonwealth Scientific and Industrial Research } \\
\text { Organization and Bureau of Meteorology, Australia }\end{array}$ & • & • & & - & - & & • & $1.25 \times 1.88$ & 38 \\
\hline BCC-CSM & $\begin{array}{l}\text { Beijing Climate Center, China Meteorological } \\
\text { Administration }\end{array}$ & • & • & & • & • & • & • & $2.79 \times 2.81$ & 26 \\
\hline CCSM4 & National Center for Atmospheric Research, USA & - & - & & - & • & & $\cdot$ & $0.94 \times 1.25$ & 26 \\
\hline CMCC-CM & $\begin{array}{l}\text { Centro Euro-Mediterraneo per I Cambiamenti } \\
\text { Climatici }\end{array}$ & • & - & & & - & & - & $0.75 \times 0.75$ & 31 \\
\hline FGOALS & $\begin{array}{l}\text { LASG, Institute of Atmospheric Physics, } \\
\text { Chinese Academy of Sciences }\end{array}$ & • & • & & • & • & - & - & $1.66 \times 2.81$ & 26 \\
\hline GFDL-ESM2M & $\begin{array}{l}\text { NOAA Geophysical Fluid Dynamics } \\
\text { Laboratory, USA }\end{array}$ & • & • & & • & • & • & • & $2.02 \times 2.5$ & 48 \\
\hline IPSL-CM5A-LR & Institut Pierre Simon Laplace, France & • & • & & $\cdot$ & $\cdot$ & - & $\cdot$ & $1.89 \times 3.75$ & 39 \\
\hline MPI-ESM-MR & Max Planck Institute for Meteorology, Germany & - & - & & - & - & - & - & $1.87 \times 1.88$ & 95 \\
\hline MRI-CGCM3 & Meteorological Research Institute, Japan & $\cdot$ & $\cdot$ & & - & $\cdot$ & & $\cdot$ & $1.12 \times 1.13$ & 48 \\
\hline NorESM1-M & Norwegian Climate Center, Norway & • & • & • & - & - & & • & $1.89 \times 2.5$ & 26 \\
\hline
\end{tabular}

The methodology for using the modeled climate data to calculate Plant Hardiness Zones within each $1 \mathrm{~km}$ cell, by finding the minimum of all the daily minimum temperatures for each year, is the same methodology used by the USDA. The average of all the annual extreme minimum temperatures for the time period of interest was then calculated. The statistics were run on netcdf files of daily minimum temperatures for each model using command line climate data operators (cdo) in a Linux environment. The final output, the average of all annual extreme minimum temperatures for each cell, was converted to a raster image for each model. Each cell was placed into specific zone categories, based on the average extreme minimum temperature, using the same criteria and categories used by the USDA (Figure 4).

To calculate shifts in Plant Hardiness Zones, the specific zones were reclassified to the general Hardiness Zone (example, Zone 3a was reclassified simply to Zone 3) for both the past and future periods. The past raster (1980-2005) of general Hardiness Zones was subtracted from the projected future raster (20252050) for each specific model to get the change, or shift, in Plant Hardiness Zone. This method is the same used by the Arbor Day Foundation to calculate the difference between their 2015 Hardiness Zones from that of the 1990 USDA Hardiness Zones (Figure 3).

\section{Hardiness Zones}

Average Annual Extreme Minimum Temperature ( ${ }^{\circ} \mathrm{F}$ )

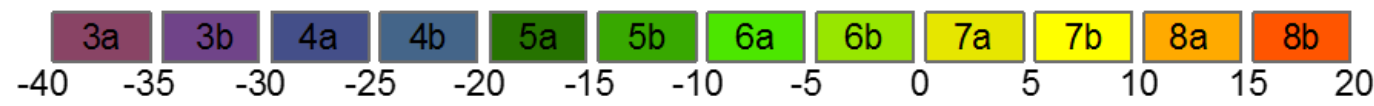

Figure 4: Plant Hardiness Zone categories, as defined by the USDA, based on Average Annual Extreme Minimum Temperature.

\footnotetext{
${ }^{4}$ For more information on the summary model data please see Sylvester, L. M. et al. (2016). Processing and Monthly Summaries of Downscaled Climate Data for Knoxville, Tennessee and Surrounding Region. Technical Report ORNL/TM-2016/486. Oak Ridge National Laboratory.
} 


\section{Results}

The results for each of the Plant Hardiness Zone calculations for each model, both past, present, and change in Zone are described below. Knox County and the watersheds that are within Knox County are highlighted on the resulting maps. The watersheds surrounding Knox County were chosen as the boundary of interest as precipitation and runoff values for green infrastructure are best defined through these area delineations. This highlighted area is therefore the main area of interest and the modeled description results describe the changes that occur within those watersheds. The specific models vary between suggesting little change to suggesting Knoxville moves into the next two Hardiness Zones. Overall, the models suggest the Knoxville area will move into the next warmer Hardiness Zone, indicating Knoxville may move into Hardiness Zone 8.

The modeled climate data for the past is modeled data from 1980-2005. This is a slightly different time period than what the USDA uses (1976-2005). The modeled data for the future is 2025-2050. USDA currently has the Knoxville area in Zone 7a while the model data places Knoxville in a cooler Hardiness Zone and projects the area to increase to Zone 7 in the future. Cold biases in modeled temperatures for the Southeastern US have been noted previously. ${ }^{5}$ The modeled temperature data for the study area appears to be slightly cooler than the actual measured temperature data and this may explain the slight zone discrepancy between the models; modeled data starting Knoxville at Plant Hardiness Zone 6 (with the exception of the CMCC and MPI models starting in Zone 5) comparing with USDA actual temperature values at Zone 7.

\subsection{ACCESS Model Plant Hardiness Zone Calculation Results}

The ACCESS climate model has the Knoxville area, from 1980-2005, beginning in Hardiness Zone 6a (Figure 5). The northern portion of Knox County and contributing watersheds are projected to warm to Hardiness Zone $7 \mathrm{a}$ for the 2025-2050 period. The southern portion is projected to warm to Hardiness Zone $7 \mathrm{~b}$. This results in an overall change of increasing much of the area by +1 Hardiness Zone. Some cells in the upper northern portions of the area are classified beginning in Zone $5 \mathrm{~b}$ resulting in a +2 Zone change between past and future.

\footnotetext{
${ }^{5}$ Mearns, L. O., Giorgi, F., McDaniel, L., \& Shields, C. (2003). Climate scenarios for the southeastern US based on GCM and regional model simulations. In Issues in the Impacts of Climate Variability and Change on Agriculture (pp. 7-35). Springer. Retrieved from http://link.springer.com/chapter/10.1007/978-94-017-1984-1_2
} 

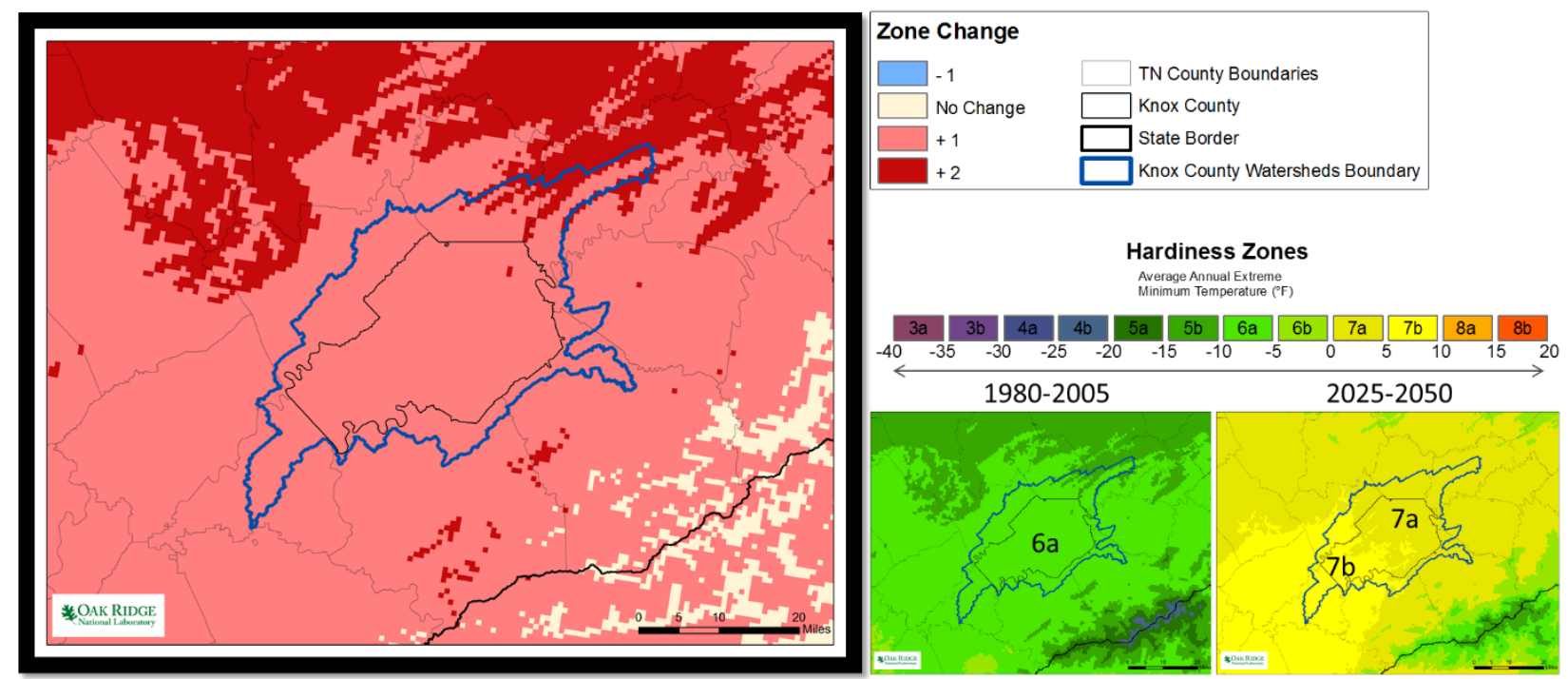

Figure 5: Knoxville, TN ACCESS Climate Model Plant Hardiness Zones for 1980-2005, 2025-2050, and the calculated past and future zone differences.

\subsection{BCC Model Plant Hardiness Zone Calculation Results}

The BCC climate model has the Knoxville area, from 1980-2005, beginning in Hardiness Zone 6a in the north and the warmer Plant Hardiness Zone $6 \mathrm{~b}$ in the south (Figure 6). The northern portion of Knox County and contributing watersheds are projected to warm to Hardiness Zone 7a for the 2025-2050 period. This results in an overall change of increasing much of the area by +1 Hardiness Zone. Some cells in the upper northern portions of the area are classified beginning in Zone 6a and warming in the future to Zone $6 \mathrm{~b}$. This results in no change for a few cells in the northern portion of the area between past and future.
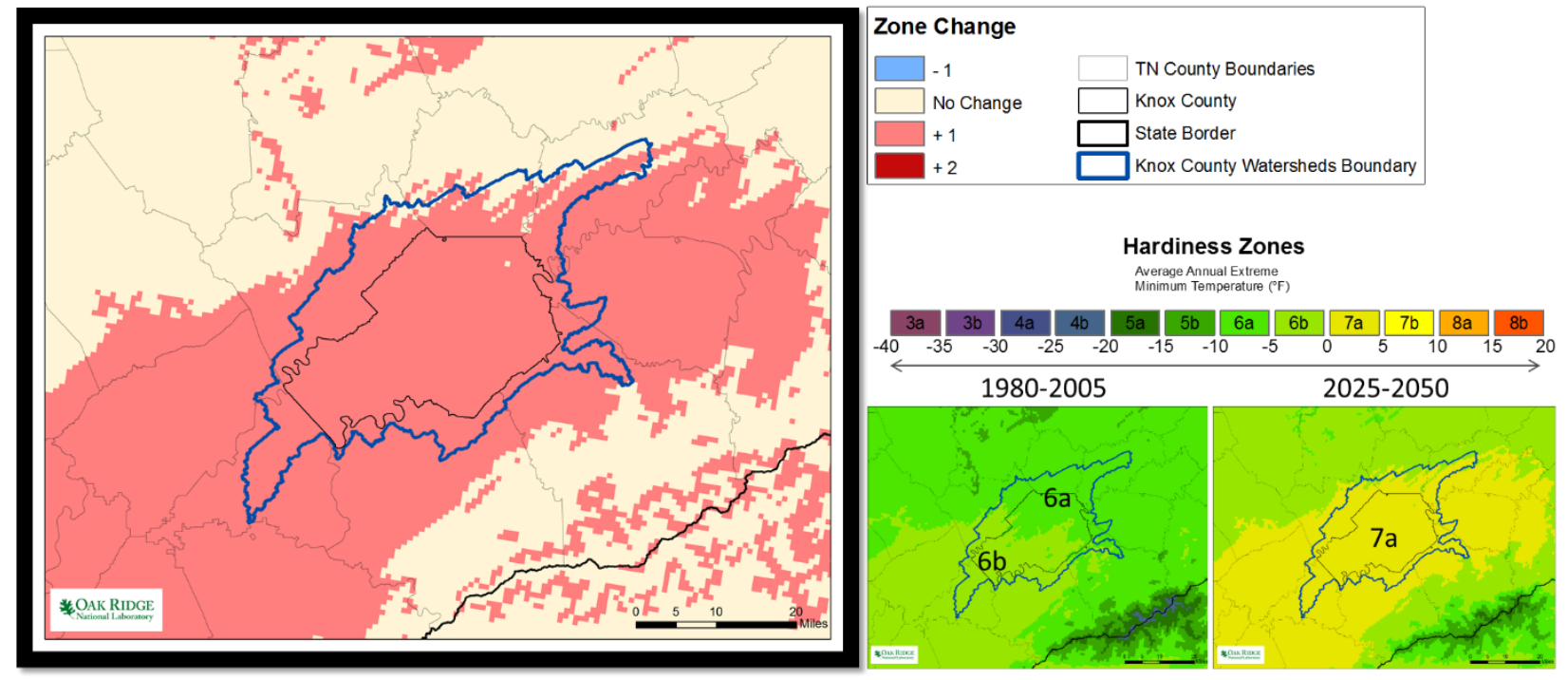

Figure 6: Knoxville, TN BCC Climate Model Plant Hardiness Zones for 1980-2005, 2025-2050, and the calculated past and future zone differences. 


\subsection{CCSM4 Model Plant Hardiness Zone Calculation Results}

The CCSM4 climate model has the Knoxville area, from 1980-2005, beginning in Hardiness Zone 6b with a few portion in the north labeled as Zone 6a (Figure 7). Much of Knox County and the contributing watersheds are projected to warm to Hardiness Zone 7 a for the 2025-2050 period. A small portion of the southern area is projected to warm to Hardiness Zone $7 \mathrm{~b}$. This results in an overall change of increasing by +1 Hardiness Zone between the past and future periods.

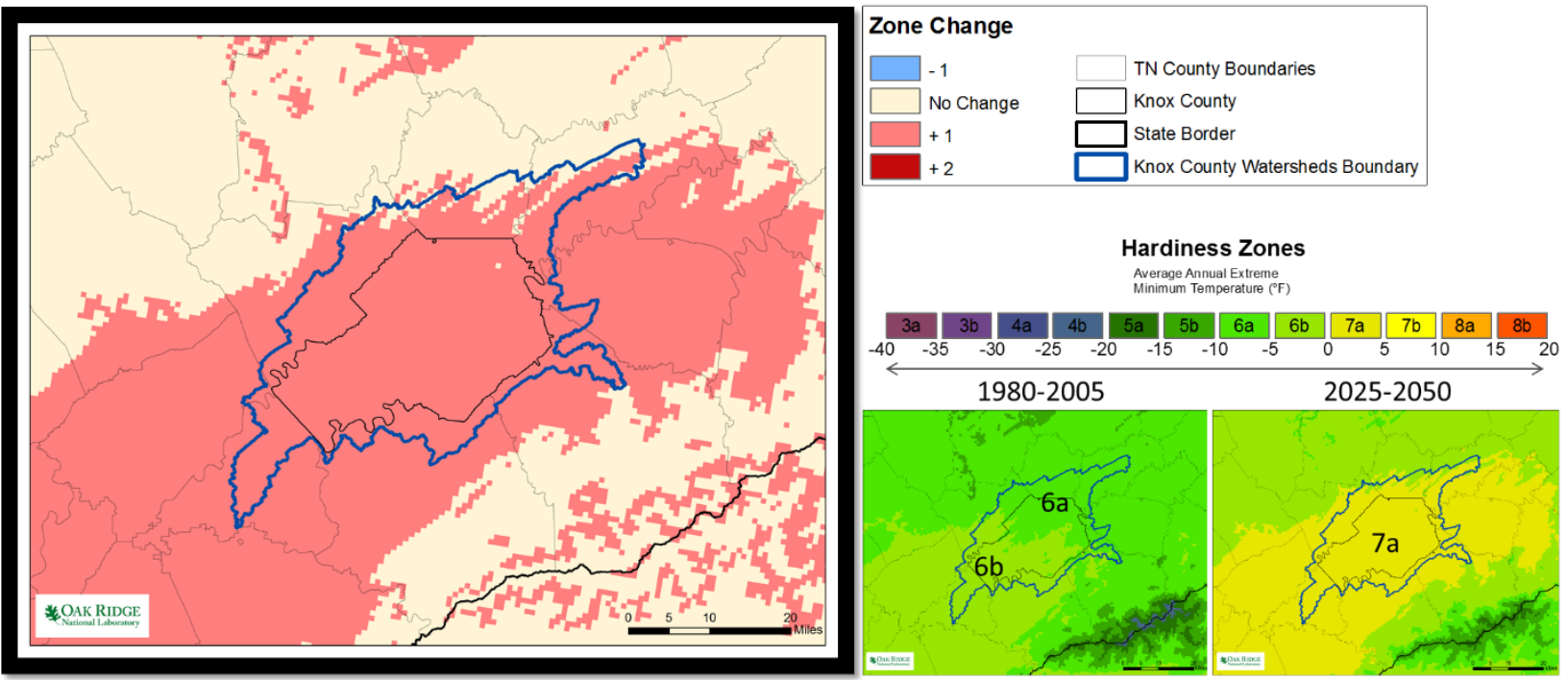

Figure 7: Knoxville, TN CCSM4 Climate Model Plant Hardiness Zones for 1980-2005, 2025-2050, and the calculated past and future zone differences. 


\subsection{CMCC Model Plant Hardiness Zone Calculation Results}

The CMCC climate model has the Knoxville area, from 1980-2005, beginning in Hardiness Zone 5b with a few portion in the north even cooler as Zone 5a (Figure 8). Knox County and the contributing watersheds are projected to warm to Hardiness Zone 7 a for the 2025-2050 period. A small portion of the northern area is projected to warm to Hardiness Zone $6 \mathrm{~b}$. This results in an overall change of increasing by +2 Hardiness Zones between the past and future periods.
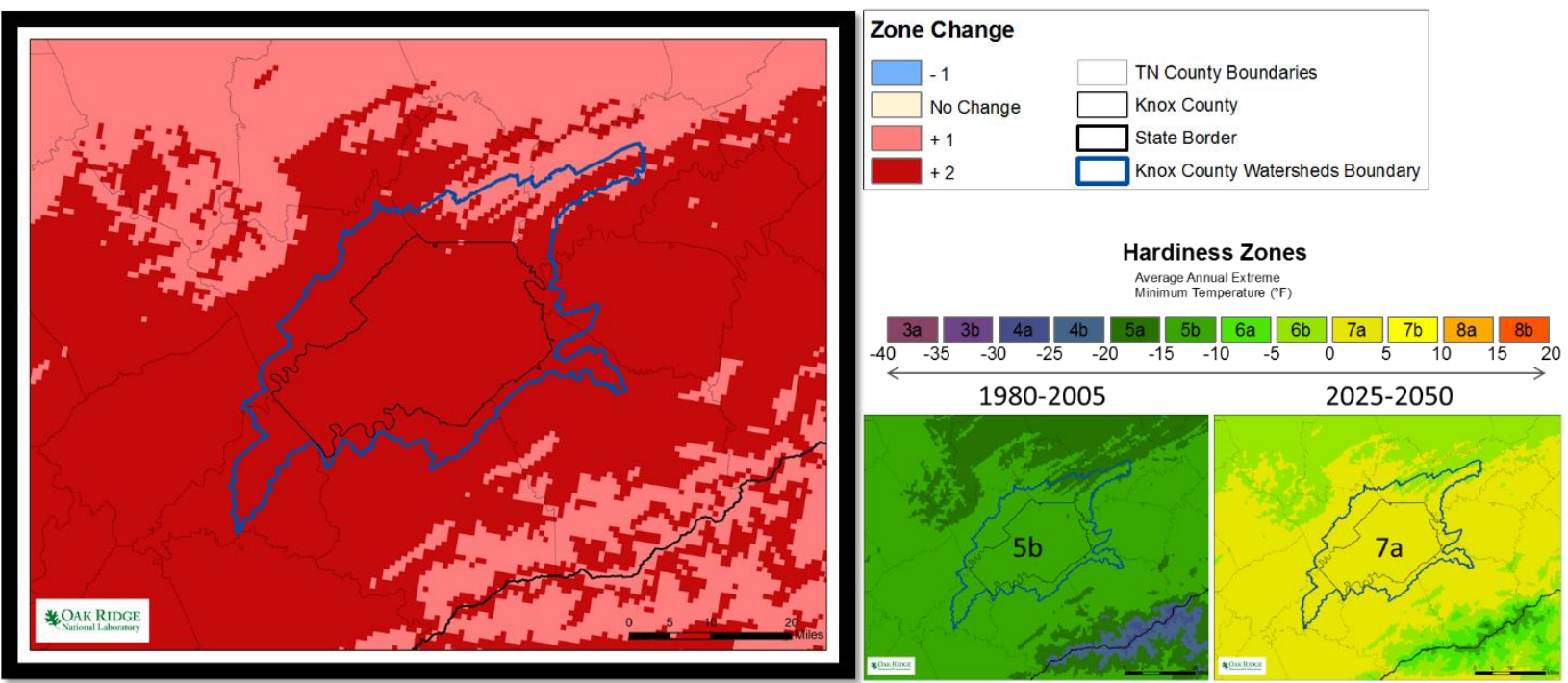

Figure 8: Knoxville, TN CMCC Climate Model Plant Hardiness Zones for 1980-2005, 2025-2050, and the calculated past and future zone differences. 


\subsection{FGALS Model Plant Hardiness Zone Calculation Results}

The FGOALS climate model has the Knoxville area, from 1980-2005, beginning in Hardiness Zone 6a with a small portion of the southern area in Zone $6 \mathrm{~b}$ (Figure 9). Most of Knox County and contributing watersheds are projected to warm to Hardiness Zone 7a for the 2025-2050 period. This results in an overall change of increasing much of the area by +1 Hardiness Zone.
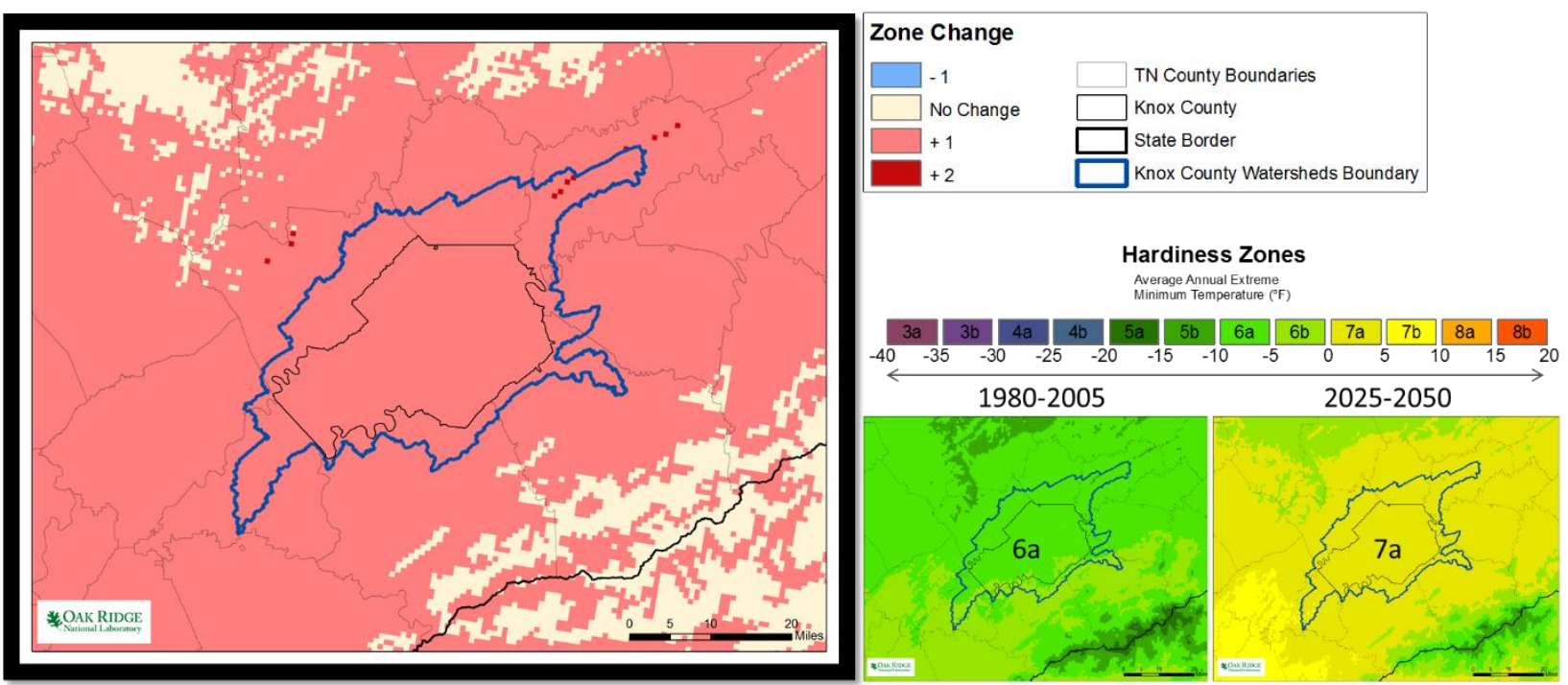

Figure 9: Knoxville, TN FGOALS Climate Model Plant Hardiness Zones for 1980-2005, 2025-2050, and the calculated past and future zone differences. 


\subsection{GFDL Model Plant Hardiness Zone Calculation Results}

The GFDL climate model has the Knoxville area, from 1980-2005, beginning in Hardiness Zone 6a with a small portion of the southern area in Zone $6 \mathrm{~b}$ (Figure 10). Most of Knox County and the contributing watersheds are projected to cool or remain the same at Hardiness Zone 6a for the 2025-2050 period. This results, overall, in no change with a slight cooling in a few cells of the northern portion decreasing the area by -1 Zone.

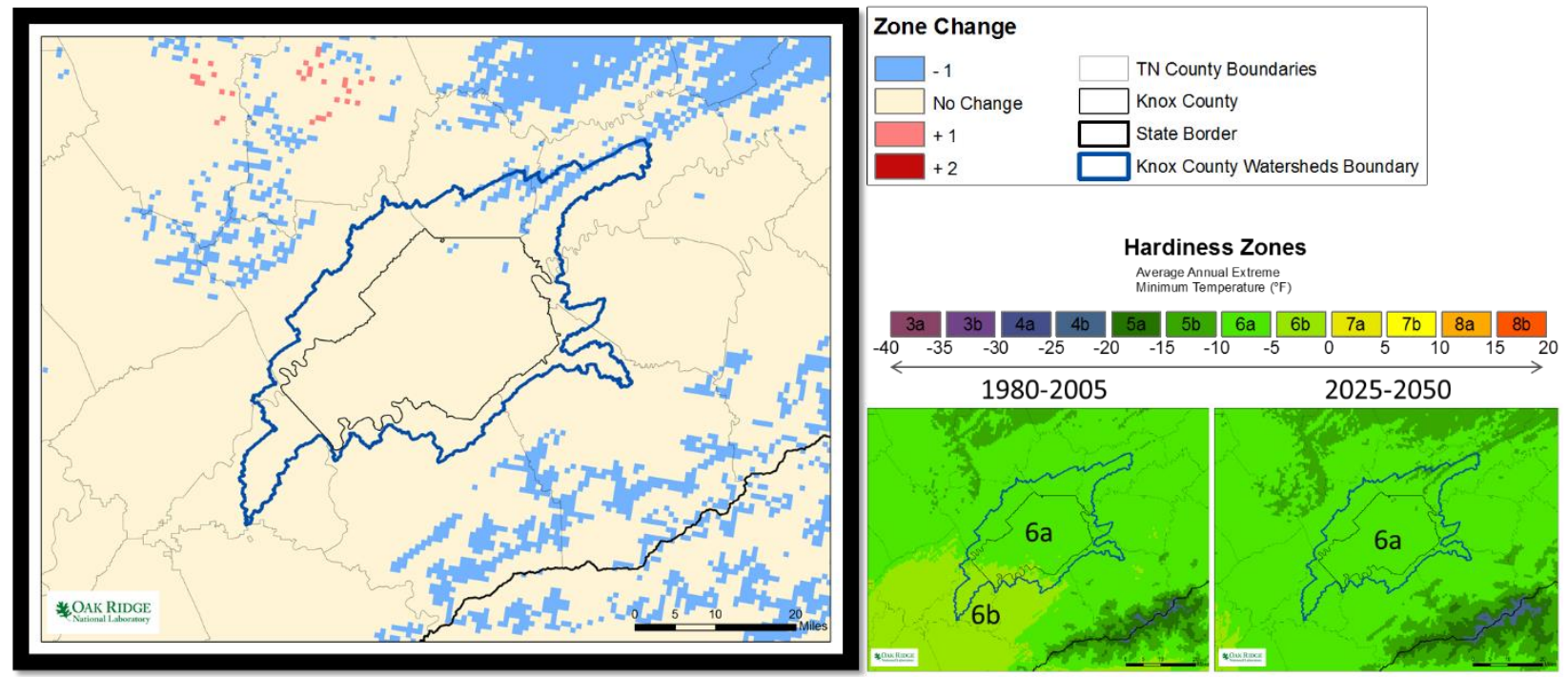

Figure 10: Knoxville, TN GFDL Climate Model Plant Hardiness Zones for 1980-2005, 2025-2050, and the calculated past and future zone differences. 


\subsection{IPSL Model Plant Hardiness Zone Calculation Results}

The IPSL climate model has the Knoxville area, from 1980-2005, beginning in Hardiness Zone 6b with a small portion of the northern area in Zone 6a (Figure 11). Most of Knox County and the contributing watersheds are projected to slightly warm to Hardiness Zone $7 \mathrm{a}$ in the south and $6 \mathrm{~b}$ in the north for the 2025-2050 period. This results, overall, in no change of Hardiness Zone in the northern area with a slight warming in the southern portion increasing the area into the next zone.

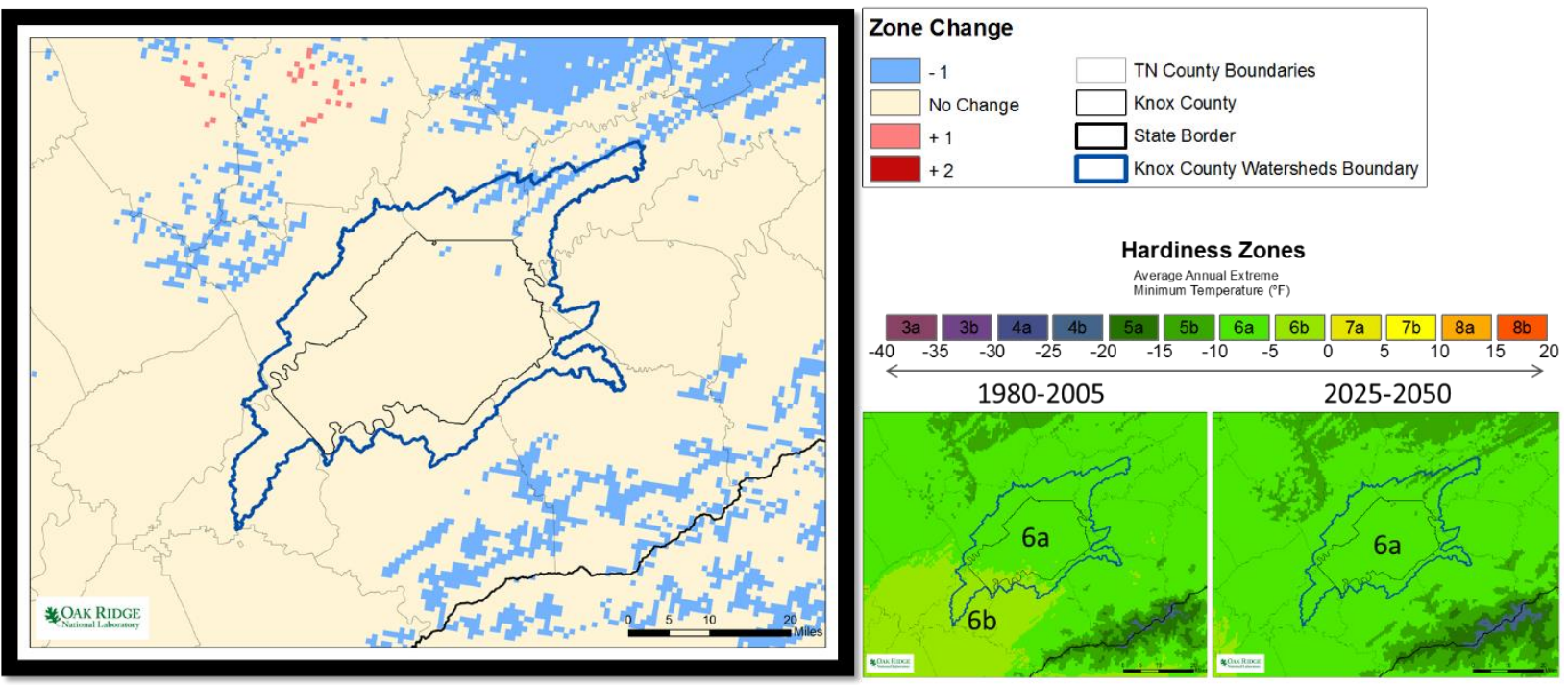

Figure 11: Knoxville, TN IPSL Climate Model Plant Hardiness Zones for 1980-2005, 2025-2050, and the calculated past and future zone differences. 


\subsection{MPI Model Plant Hardiness Zone Calculation Results}

The MPI climate model has the Knoxville area, from 1980-2005, beginning in Hardiness Zone 5b with a small portion of the southern area in Zone 6a (Figure 12). Most of Knox County and the contributing watersheds are projected to warm to Hardiness Zone 7a for the 2025-2050 period. This results, overall, in a warming to increase the area by +2 Plant Hardiness Zones. A small portion of the southern watersheds and a few cells in the north warm as well but only to create a +1 Zone increase.
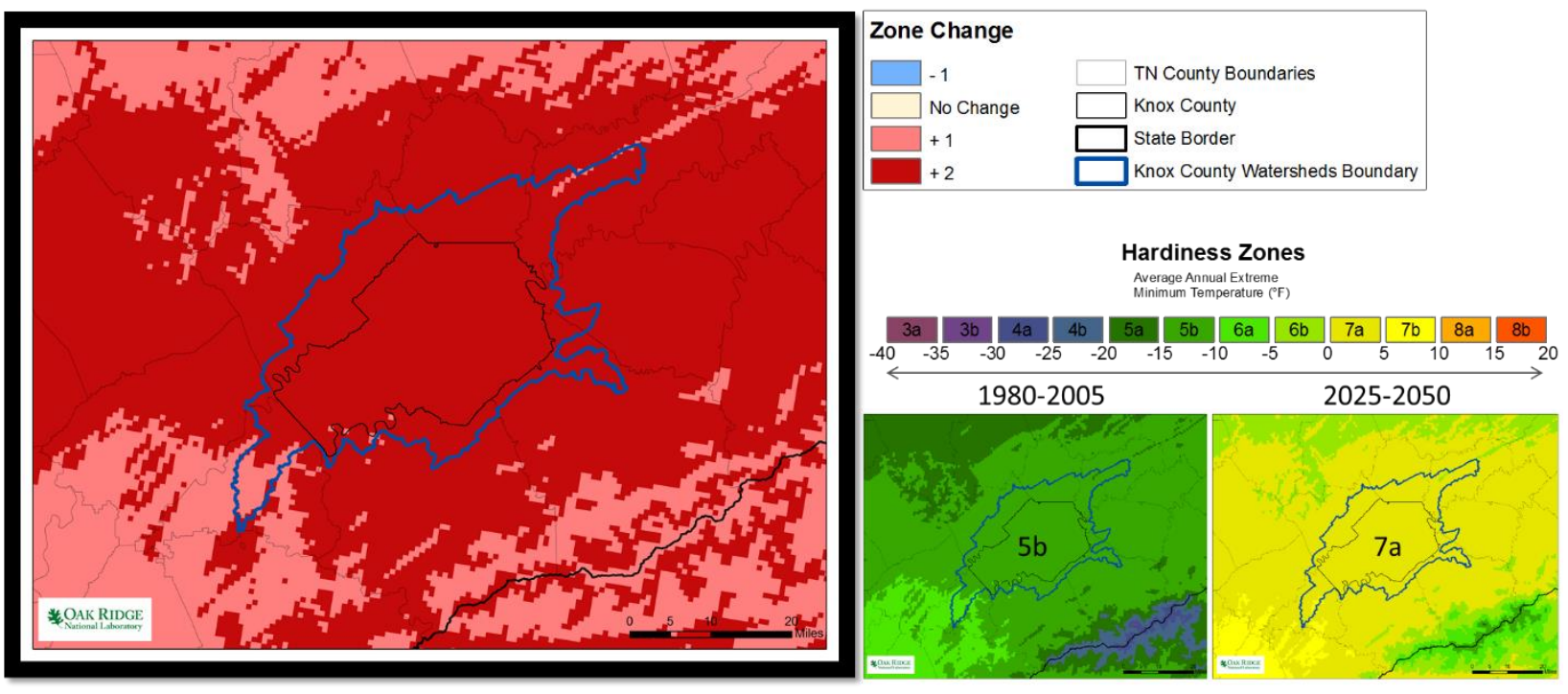

Figure 12: Knoxville, TN MPI Climate Model Plant Hardiness Zones for 1980-2005, 2025-2050, and the calculated past and future zone differences. 


\subsection{MRI Model Plant Hardiness Zone Calculation Results}

The MRI climate model has the Knoxville area, from 1980-2005, beginning in Hardiness Zone 6a with a small portion of the north in Zone $5 \mathrm{~b}$ (Figure 13). The southern portion of Knox County and contributing watersheds are projected to warm to Hardiness Zone $6 \mathrm{~b}$ for the $2025-2050$ period. The northern portion is projected to warm or stay the same at Hardiness Zone 6a. This results in no overall change of Hardiness Zone with a small portion of the northern area warming by +1 Hardiness Zone.
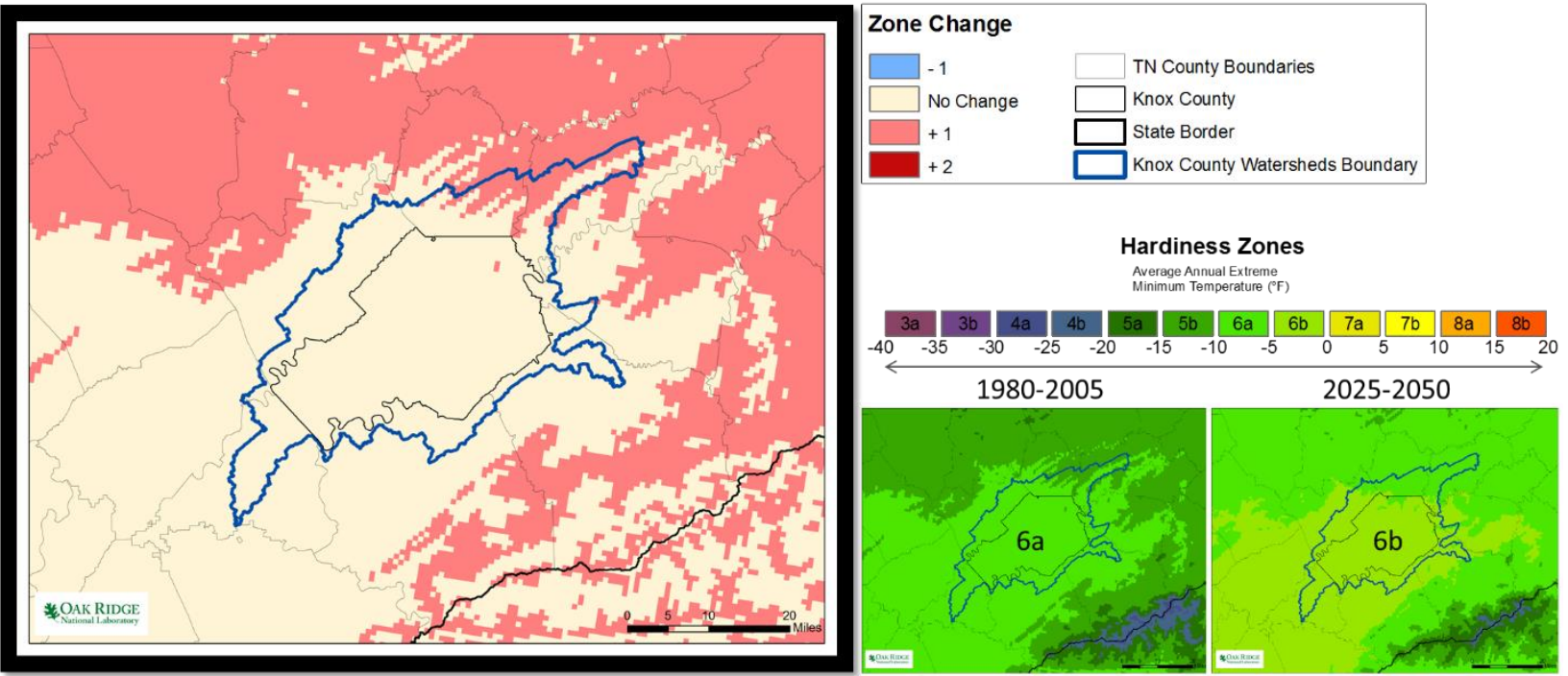

Figure 13: Knoxville, TN MRI Climate Model Plant Hardiness Zones for 1980-2005, 2025-2050, and the calculated past and future zone differences. 


\subsection{NorESM Model Plant Hardiness Zone Calculation Results}

The NorESM climate model has the Knoxville area, from 1980-2005, beginning in Hardiness Zone 6a with a small portion of the south in Zone 6b (Figure 14). Much of Knox County and the contributing watersheds are projected to warm to Hardiness Zone 7a for the 2025-2050 period. This results in an overall change of warming to the next Zone increasing by +1 Hardiness Zone.
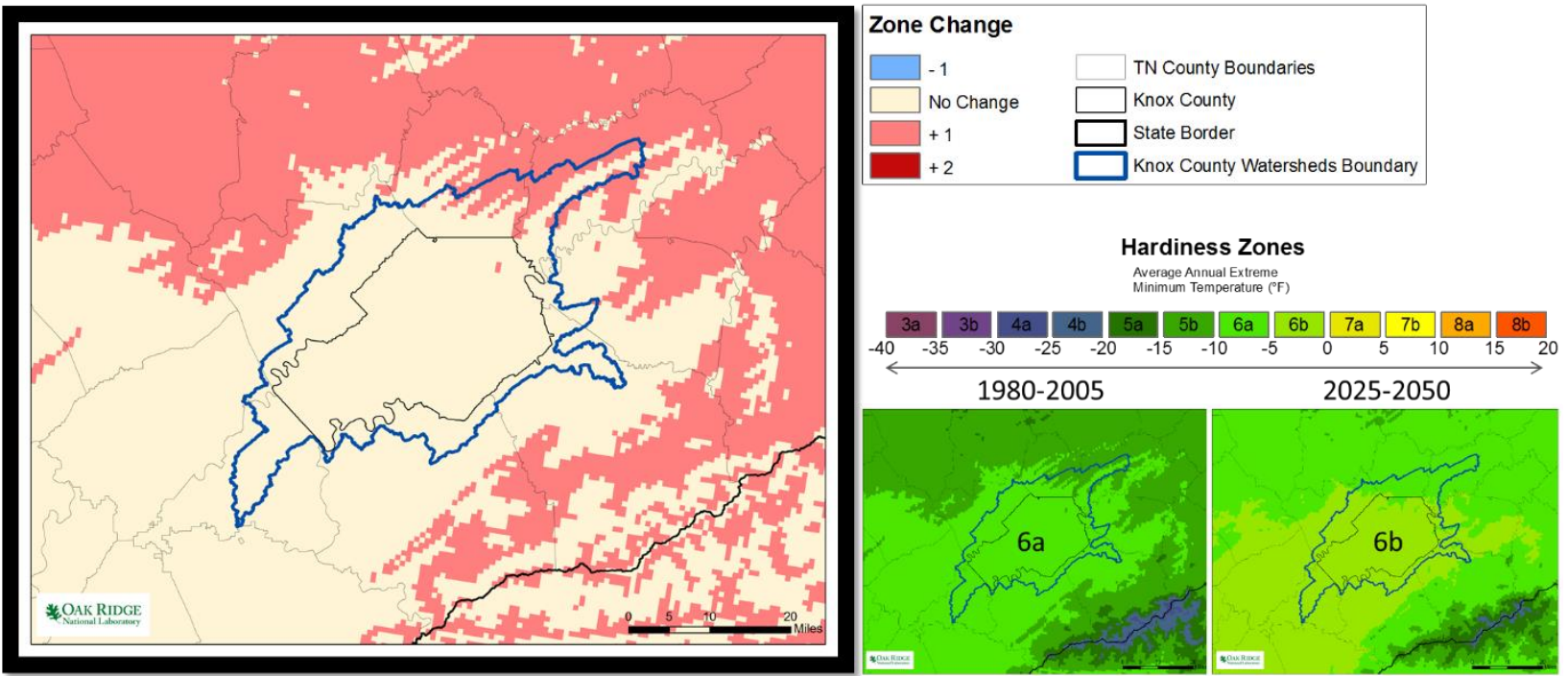

Figure 14: Knoxville, TN NorESM Climate Model Plant Hardiness Zones for 1980-2005, 2025-2050, and the calculated past and future zone differences. 


\subsection{Summary of Climate Model Plant Hardiness Zone Calculations}

The summary of past and future climate model calculations of Hardiness Zones are shown in Table 2. The primary modeled conditions for past and future Hardiness Zones are listed only for the watersheds that contribute to Knox County. In Table 2, font size of the Zone designations increases proportionally with increasing average extreme minimum temperature. The individual models vary between suggesting little change to the Plant Hardiness Zones to suggesting Knoxville moves into the next two Hardiness Zones. Overall, the models suggest moving into the next warmer Zone.

Table 2: Summary of Climate Model Plant Hardiness Zone Calculations for Past and Future Conditions within Knox County Watersheds

\begin{tabular}{|l|c|c|c|}
\hline Model & $\begin{array}{c}\text { Hardiness Zones } \\
\text { for Past Conditions } \\
1980-2005\end{array}$ & $\begin{array}{c}\text { Hardiness Zones for } \\
\text { Future Conditions } \\
2025-2050\end{array}$ & $\begin{array}{c}\text { Overall Hardiness } \\
\text { Zone Difference }\end{array}$ \\
\hline ACCESS & $6 \mathrm{a}$ & $7 \mathrm{a}, 7 \mathrm{~b}$ & +1 \\
\hline BCC & $6 \mathrm{a}, 6 \mathrm{~b}$ & $7 \mathrm{a}$ & +1 \\
\hline CCSM4 & $6 \mathrm{~b}$ & $7 \mathrm{a}, 7 \mathrm{~b}$ & +1 \\
\hline CMCC & $5 \mathrm{~b}$ & $7 \mathrm{a}$ & +1 \\
\hline FGOALS & $6 \mathrm{a}$ & $7 \mathrm{a}$ & No change \\
\hline GFDL & $6 \mathrm{a}, 6 \mathrm{~b}$ & $6 \mathrm{a}$ & +1 \\
\hline IPSL & $6 \mathrm{~b}$ & $6 \mathrm{~b}, 7 \mathrm{a}$ & +2 \\
\hline MPI & $5 \mathrm{~b}$ & $7 \mathrm{a}$ & No change \\
\hline MRI & $6 \mathrm{a}$ & $6 \mathrm{~b}$ & +1 \\
\hline NorESM & $6 \mathrm{a}$ & $7 \mathrm{a}$ &
\end{tabular}




\section{Conclusion}

Overall, the ten climate models used to calculate Plant Hardiness Zones and the changes that occur between periods 1980-2005 and 2025-2050 indicate that the Knoxville, TN area and surrounding watersheds will increase to the next warmer Plant Hardiness Zone. The specific models vary between suggesting little change (GFDL and MRI models) to suggesting Knoxville moves into the next two Hardiness Zones (CMCC and MPI models). While the modeled temperatures for the recent past indicate starting at slightly cooler temperatures then observed, and therefore a lower Hardiness Zone, the models suggest warming in the future will move the area into the next Plant Hardiness Zone. As Knoxville, according to USDA, is currently in Zone 7a, this means that the climate may change in the future to move Knoxville into Hardiness Zone 8.

As far as tree species that may be chosen for green infrastructure installations, a list of recommended trees from the city of Knoxville was sampled ${ }^{6}$ and the Plant Hardiness Zones for each species were researched and reviewed ${ }^{7}$. From the sample (Table 3), many of the native trees that are recommended for urban areas are still expected to be suitable even with a future warming into the next Plant Hardiness Zone of Zone 8. Several of the trees may be at the limit of their ideal Hardiness Zones but this should not deter from planting. The non-native species, again recommended for urban plantings, also had trees that were still within their recommended Hardiness Zone. Several trees on this list were, again at their limit, and one tree species will be outside of its Hardiness Zone if the climate does indeed warm enough to move Knoxville to Hardiness Zone 8. This list (Table 3) is merely a sample of trees and is by no means complete. A more detailed (but still not to be considered complete) list for the Knoxville, Tennessee area can be found in Appendix A. More research is needed to determine a more complete picture of the effect an increased Hardiness Zone will have on tree and plant recommendations for the city of Knoxville.

Table 3: A sample of Hardiness Zones of trees recommended for planting in urban areas of Knoxville, TN.

\begin{tabular}{llll}
\hline Native Species & $\underline{\text { Zones }}$ & Non-native Species & $\underline{\text { Zones }}$ \\
\hline Kentucky Coffeetree & $3-8$ & London Planetree & $5-9$ \\
Thornless Honeylocust & $3-9$ & Sawtooth Oak & $5-9$ \\
Willow Oak & $5-9$ & Trident Maple & $5-8$ \\
\hline Shumard Oak & $5-9$ & Chinese Pistache & $6-9$ \\
Bald Cypress & $4-10$ & Silver Linden & $4-7$ \\
Yellowwood & $4-8$ & Lace-bark Elm & $5-9$ \\
Eastern Hophornbean & $3-9$ & Zelkova & $5-8$ \\
Overcup Oak & $5-9$ & Kousa Dogwood & $5-8$ \\
Eastern Redbud & $4-9$ & Crapemyrtle & $7-10$ \\
\hline
\end{tabular}

If the Knoxville area shifts into the next warmer Hardiness Zone:

Trees at their Hardiness Zone limit

Trees outside their Hardiness Zone limit

\footnotetext{
${ }^{6}$ http://www.knoxvilletn.gov/UserFiles/Servers/Server_109478/File/PublicService/Trees/trees.pdf

${ }^{7}$ https://www.arborday.org/trees/TreeGuide/TreeList.cfm
} 
APPENDIX A. Hardiness Zones for Recommended Trees in Knoxville, Tennessee 


\section{APPENDIX A. HARDINESS ZONES FOR RECOMMENDED TREES IN KNOXVILLE, TENNESSEE}

The following list of trees is from the Urban Forestry Division of the City of Knoxville, Tennessee. ${ }^{8}$ The Hardiness Zones for each tree in the list has been added, with color coding to indicate the possible limits to the tree's Hardiness Zones in the future (as calculated in this report). The list includes large trees, whose mature height is greater than 50 feet, medium trees (mature height 30-50 feet), small trees (mature height less than 30 feet), and then tree separated into fruit and nut tree categories and trees for screening purposes. The last two categories may include trees from the large, medium, and small categories but are just further distinguished by these special categories. Some various cultivars are also indicated in the lists.

${ }^{8}$ http://www.knoxvilletn.gov/government/city_departments_offices/public_service/urban_forestry/ 
Knoxville List of Trees (http://www.knoxvilletn.gov/UserFiles/Servers/Server_109478/File/PublicService/Trees/trees.pdf) If the Knoxville area shifts into the next warmer Hardiness Zone (Zone 8):

Trees at their Hardiness Zone limit

Trees outside their Hardiness Zone limi

\section{Large Trees}

\begin{tabular}{|c|c|}
\hline Tree & Hardiness Zone \\
\hline Red Maple* (Acer rubrum) & $3-9$ \\
\hline Sugar Maple* (Acer saccharum ) & $3-8$ \\
\hline Yellow Buckeye* (Aesculus flava) & $4-8$ \\
\hline Pecan* (Carya illinoinensis ) & $6-9$ \\
\hline Common Hackberry* (Celtis occidentalis ) & $3-9$ \\
\hline American Beech* (Fagus grandifolia ) & $4-9$ \\
\hline European Beech (Fagus sylvatica ) & $4-7$ \\
\hline Ginkgo (Ginkgo biloba ) MALE ONLY & $3-8$ \\
\hline Thornless Honeylocust* (Gleditsia triacanthos ) & $3-9$ \\
\hline Kentucky Coffeetree* (Gymnocladus dioica ) & $3-8$ \\
\hline Sweetgum* (Liquidambar styraciflua) & $5-9$ \\
\hline Tulip Poplar* (Liriodendron tulipifera ) & $4-9$ \\
\hline Cucumbertree Magnolia (Magnolia acuminata ) & $3-8$ \\
\hline Southern Magnolia* (Magnolia grandiflora ) & $6-10$ \\
\hline Dawn Redwood (Metasequoia glyptostroboides ) & $5-8$ \\
\hline Blackgum* (Nyssa sylvatica) & $4-9$ \\
\hline Shortleaf Pine* (Pinus echinata ) & $6-9$ \\
\hline Pitch Pine* (Pinus rigida & $4-7$ \\
\hline White Pine* (Pinus strobus) & $3-8$ \\
\hline Loblolly Pine* (Pinus taeda ) & $6-9$ \\
\hline Virginia Pine* (Pinus virginiana ) & $5-8$ \\
\hline London Planetree (Platanus X acerifolia ) & $5-9$ \\
\hline American Sycamore* (Platanus occidentalis ) & $4-9$ \\
\hline Sawtooth Oak (Quercus acutissima ) & $5-9$ \\
\hline White Oak* (Quercus alba) & $3-9$ \\
\hline Swamp White Oak* (Quercus bicolor ) & $3-8$ \\
\hline Scarlet Oak* (Quercus coccinea ) & $4-9$ \\
\hline Laurel Oak (Quercus hemisphaerica ) & $6-10$ \\
\hline Southern Red Oak* (Quercus falcata ) & $5-9$ \\
\hline Bur Oak* (Quercus macrocarpa ) & $3-8$ \\
\hline Swamp Chestnut Oak* (Quercus michauxii) & $5-9$ \\
\hline Chinkapin Oak* (Quercus muehlenbergii) & $4-7$ \\
\hline Pin Oak* (Quercus palustris ) & $4-8$ \\
\hline Willow Oak* (Quercus phellos ) & $5-9$ \\
\hline Chestnut Oak* (Quercus prinus ) & $4-8$ \\
\hline English Oak (Quercus robur) & $5-8$ \\
\hline Northern Red Oak* (Quercus rubra) & $3-8$ \\
\hline Shumard Oak* (Quercus shumardii) & $5-9$ \\
\hline Black Oak* (Quercus velutina ) & $3-9$ \\
\hline Bald Cypress* (Taxodium distichum ) & $4-10$ \\
\hline American Basswood* (Tilia americana ) & $2-8$ \\
\hline Winged Elm* (Ulmus alata ) & $6-9$ \\
\hline American Elm* (Ulmus americana ) & $2-9$ \\
\hline
\end{tabular}


Knoxville List of Trees (http://www.knoxvilletn.gov/UserFiles/Servers/Server_109478/File/PublicService/Trees/trees.pdf) If the Knoxville area shifts into the next warmer Hardiness Zone (Zone 8):

Trees at their Hardiness Zone limit

rees outside their Hardiness Zone limi

\section{Medium Trees}

\begin{tabular}{|c|c|}
\hline Tree & Hardiness Zone \\
\hline Hedge Maple (Acer campestre ) & $5-8$ \\
\hline Trident Maple (Acer buergerianum ) & $5-8$ \\
\hline River Birch* (Betula nigra ) & $4-9$ \\
\hline European Hornbeam (Carpinus betulus ) & $4-8$ \\
\hline American Hornbeam* (Carpinus caroliniana ) & $3-9$ \\
\hline Catalpa* (Catalpa speciosa) & $4-8$ \\
\hline Atlas Cedar (Cedrus atlantica ) & $6-9$ \\
\hline Deodar Cedar (Cedrus deodara ) & $7-9$ \\
\hline Atlantic White Cedar (Chamaecyparis thyoides ) & $4-8$ \\
\hline Yellowwood* (Cladrastis kentukea) & $4-8$ \\
\hline Turkish Fibert (Corylus colurna & $4-7$ \\
\hline Cryptomeria (Cryptomeria japonica ) & $5-9$ \\
\hline American Persimmon* (Diospyros virginiana ) & $4-9$ \\
\hline Hardy Rubber Tree (Eucommia ulmoides & $4-7$ \\
\hline American Holly* (Ilex opaca ) & $5-9$ \\
\hline Eastern Red Cedar* (Juniperus virginiana ) & $3-9$ \\
\hline Golden Raintree (Koelreuteria paniculata ) & $5-9$ \\
\hline Sweetbay Magnolia* (Magnolia virginiana ) & $5-10$ \\
\hline Eastern Hophornbean* (Ostrya virginiana ) & $3-9$ \\
\hline Sourwood* (Oxydendrum arboreum ) & $5-9$ \\
\hline Austrian Pine (Pinus nigra & $4-7$ \\
\hline Japanese Red Pine (Pinus densiflora & $3-7$ \\
\hline Chinese Pistache (Pistacia chinensis ) & $6-9$ \\
\hline Overcup Oak* (Quercus lyrata ) & $5-9$ \\
\hline Black Locust* (Robinia pseudoacacia ) & $3-8$ \\
\hline Weeping Willow (Salix babylonica ) & $6-8$ \\
\hline Sassafras* (Sassafras albidum ) & $4-9$ \\
\hline Japanese Pagoda (Sophora japonica ) & $4-8$ \\
\hline Little-leaf Linden (Tilia cordata ) & $3-7$ \\
\hline Silver Linden (Tilia tomentosa ) & $4-7$ \\
\hline Smooth Leaf Elm (Ulmus carpinifolia & $5-7$ \\
\hline Lace-bark Elm (Ulmus parvifolia ) & $5-9$ \\
\hline Zelkova (Zelkova serrata ) & $5-8$ \\
\hline
\end{tabular}


Knoxville List of Trees (http://www.knoxvilletn.gov/UserFiles/Servers/Server_109478/File/PublicService/Trees/trees.pdf) If the Knoxville area shifts into the next warmer Hardiness Zone (Zone 8):

Trees at their Hardiness Zone limit

rees outside their Hardiness Zone limi

\section{Small Trees}

\begin{tabular}{|l|l|}
\hline Tree & Hardiness Zone \\
\hline Amur Maple (Acer ginnala ) & $3-8$ \\
\hline Paperbark Maple (Acer griseum) & $4-8$ \\
\hline Japanese Maple (Acer palmatum) & $5-8$ \\
\hline Red Buckeye* (Aesculus pavia ) & $4-8$ \\
\hline Serviceberry* (Amelanchier spp.) & $\sim 4-9$ \\
\hline Pawpaw* (Asimina triloba ) & $5-9$ \\
\hline Eastern Redbud* (Cercis canadensis ) & $4-9$ \\
\hline Chinese Fringetree (Chionanthus retusus ) & $5-9$ \\
\hline American Fringetree* (Chionanthus virginicus ) & $4-8$ \\
\hline Pagoda Dogwood (Cornus alternifolia ) & $3-7$ \\
\hline Flowering Dogwood* (Cornus florida ) & $5-9$ \\
\hline Kousa Dogwood (Cornus kousa ) & $5-8$ \\
\hline European Smoketree (Cotinus coggygria ) & $5-8$ \\
\hline American Smoketre** (Cotinus obovatus ) & $4-8$ \\
\hline Cockspur Hawthorn (Crataegus crusgalli) & $3-7$ \\
\hline Carolina Silverbell* (Halesia tetraptera ) & $4-8$ \\
\hline Witch-hazel* (Hamamelis virginiana ) & $3-8$ \\
\hline Foster Holly (Ilex x attenuate 'Fosteri') & $6-9$ \\
\hline Crapemyrtle (Lagerstroemia indica ) & $7-9$ \\
\hline Amur Maackia (Maackia amurensis ) & $3-7$ \\
\hline 'Little Gem' Magnolia (Magnolia grandiflora ) & $7-9$ \\
\hline Flowering Crabapple (Malus spp.) & $\sim 4-8$ \\
\hline Persian Ironwood (Parrotia persica ) & $4-8$ \\
\hline Oriental Cherries (Prunus serrulata ) & $5-8$ \\
\hline Mountain Stewartia (Stewartia ovata ) & $5-9$ \\
\hline Rusty Blackhaw* (Viburnum rufidulum ) & $5-9$ \\
\hline & \\
\hline
\end{tabular}


Knoxville List of Trees (http://www.knoxvilletn.gov/UserFiles/Servers/Server_109478/File/PublicService/Trees/trees.pdf) If the Knoxville area shifts into the next warmer Hardiness Zone (Zone 8):

Trees at their Hardiness Zone limit

rees outside their Hardiness Zone limi

\section{Fruit and Nut Trees}

\begin{tabular}{|l|l|}
\hline Tree & Hardiness Zone \\
\hline Serviceberry* (Amelanchier spp.) & $\sim 4-9$ \\
\hline Pawpaw* (Asimina triloba ) & $5-9$ \\
\hline Pecan* (Carya illinoinensis ) & $6-9$ \\
\hline Chinese chestnut (Castanea mollissima ) & $4-8$ \\
\hline American hazelnut* (Corylus americana ) & $4-9$ \\
\hline Turkish Fibert (Corylus colurna ) & $4-7$ \\
\hline American Persimmon* (Diospyros virginiana ) & $4-9$ \\
\hline Japanese Persimmon (Diospyros kaki ) & $7-10$ \\
\hline Ginkgo (Ginkgo biloba ) & $3-8$ \\
\hline Black walnut* (Juglans nigra ) & $4-9$ \\
\hline Edible apple (Malus pumila ) & $5-8$ \\
\hline White mulberry (Morus alba ) & $4-8$ \\
\hline Red mulberry* (Morus rubra ) & $4-8$ \\
\hline American plum* (Prunus americana) & $3-8$ \\
\hline Chickasaw plum (Prunus angustifolia ) & $5-9$ \\
\hline Sweet cherry (Prunus avium) & $3-8$ \\
\hline Sour cherry (Prunus cerasus ) & $4-8$ \\
\hline Common peach (Prunus persica ) & $5-8$ \\
\hline Common pear (Pyrus communis ) & $5-7$ \\
\hline
\end{tabular}


Knoxville List of Trees (http://www.knoxvilletn.gov/UserFiles/Servers/Server_109478/File/PublicService/Trees/trees.pdf)

If the Knoxville area shifts into the next warmer Hardiness Zone (Zone 8):

Trees at their Hardiness Zone limit

rees outside their Hardiness Zone limi

\section{Trees for Screening Purposes}

\begin{tabular}{|c|c|}
\hline Tree & Hardiness Zone \\
\hline Japanese Maple (Acer palmatum ) Several cultivars & $\begin{array}{l}\text { Osakazuki (5-9), Red Select (5-9), } \\
\text { Bloodgood }(5-8)\end{array}$ \\
\hline $\begin{array}{l}\text { European hornbeam (Carpinus betulus ) Frans Fontaine, } \\
\text { Fastigiata }\end{array}$ & Frans Fontaine $(4-8)$, Fastigiata $(4-8)$ \\
\hline Hinoki Falsecypress (Chamaecyparis obtusa) Several cultivars & Slender $(4-8)$, Golden $(4-8)$ \\
\hline Alaska-cedar (Chamaecyparis nootkatensis ) Several cultivars & Pendula $(4-7)$ \\
\hline Sawara falsecypress (Chamaecyparis pisifera ) Several cultivars & $\begin{array}{l}\text { Golden Mop (5-7), Boulevard (4-8), } \\
\text { Sungold }(3-7)\end{array}$ \\
\hline Alantic whitecedar (Chamaecyparis thyoides) Several cultivars & Shiva $(4-8)$ \\
\hline Kousa Dogwood (Cornus kousa ) Several cultivars & Milky Way (4-8), Madison (4-8) \\
\hline Pagoda Dogwood (Cornus alternifolia ) Dense compact varieties & Variegata $(5-8)$ \\
\hline $\begin{array}{l}\text { European Smoketree (Cotinus coggygria ) Dense compact } \\
\text { varieties }\end{array}$ & Ancot $(5-8)$, Young Lady $(4-8)$ \\
\hline $\begin{array}{l}\text { American Smoketree (Cotinus obovatus ) Dense compact } \\
\text { varieties }\end{array}$ & $4-8$ \\
\hline Cryptomeria (Cryptomeria japonica ) Radicans, & $5-9$ \\
\hline Leyland cypress (x Cupressocyparis leylandii) Several cultivars & $6-10$ \\
\hline Foster Holly (Ilex x attenuate 'Fosteri') Several cultivars & $6-9$ \\
\hline Nellie Stevens Holly (Ilex x'Nellie R Stevens') Several cultivars & $6-9$ \\
\hline American Holly (Ilex opaca ) Greenleaf & $5-9$ \\
\hline Witch-hazel* (Hamamelis virginiana ) & $3-8$ \\
\hline Chinese Juniper (Juniperus chinensis ) Keteleeri & $4-9$ \\
\hline Rocky Mountain Juniper (Juniperus scopulorum ) Spartan & Wichita Blue (3-7) \\
\hline $\begin{array}{l}\text { Eastern Red Cedar (Juniper virginiana ) Brodie, Berkie, } \\
\text { Canaertii }\end{array}$ & Brodie (3-9), Burkii (3-9), Canaertii (3-9) \\
\hline $\begin{array}{l}\text { Crapemyrtle (Lagerstroemia indica ) Tuscarora, Muskogee, } \\
\text { Natchez, }\end{array}$ & $\begin{array}{l}\text { Tuscarora (6-9), Muskogee (6-9), Latchez } \\
(6-9)\end{array}$ \\
\hline American Sweetgum (Liquidambar styraciflua ) & $5-9$ \\
\hline Southern Magnolia (Magnolia grandiflora) Little Gem, Alta & Little Gem $(7-9)$, Alta $(6-10)$ \\
\hline Sweetbay magnolia (Magnolia virginiana ) & $5-10$ \\
\hline Norway spruce (Picea abies ) Many cultivars & \\
\hline Eastern white pine (Pinus strobus ) Many cultivars & Sea Urchin $(3-8)$, Horsford $(3-8)$ \\
\hline Weeping Cherry (Prunus subhirtella ) & $4-8$ \\
\hline $\begin{array}{l}\text { Cherry Laurel (Prunus caroliniana ) Bright N Tight, Cherry } \\
\text { Ruffles }\end{array}$ & $\begin{array}{l}\text { Bright N Tight (7-11), Cherry Ruffles (6- } \\
\text { 11) }\end{array}$ \\
\hline English Oak (Quercus robur) Regal Prince, Skyrocket & Regal Prince (4-7), Skyrocket(4- \\
\hline Pin Oak (Quercus palustris ) Green Pillar & $4-8$ \\
\hline $\begin{array}{l}\text { Eastern arborvitae (Thuja occidentalis ) Emerald, Green Giant, } \\
\text { Nigra, Techny }\end{array}$ & $\begin{array}{l}\text { Emerald (3-7), Green Giant (5-7), } \\
(3-7), \text { Techny }(3-7)\end{array}$ \\
\hline Eastern hemlock (Tsuga canadensis ) Many cultivars & \\
\hline Viburnum spp. (Viburnum spp.) Dense compact varieties & rhytidophyllum (5-8), \\
\hline
\end{tabular}

